
NASA Technical Memorendum 84337

\section{Fire Resistant Films for Aircraft Applications}

Demetrius A. Kourtides, NASA Ames Research Center, Moffett Field, California

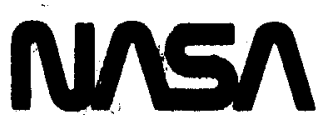

National Aeronautics and

Space Administration

Ames Recenroh Conter 
Nat Ional Aeronaut1ca and Space Admintetration

Ames Research Center

Moffett Field, Callfornie 94035

FIRE RESISTANT FILMS FOR AIRCRAET APPLICATIONS

ABSTRACT: Alternative sandwich-panel decorative films were investigated as replacements for the polyvinyl fluoride currently used in aircraft interfors. Candidate films were studied for flammability, smoke eniasion, toxic gas emission, flame spread, and sultability as a printing surface for the decorative acrylic ink system. Several of the candidate films teoted were flame-modified polyvinyl fluoride, polyvinylidene fluoride, polyimide, polyamide, polysulfone, polyphenylsulfone, polyethersulfone, polybenzimidazole, polycarbonate, polyparabanic acid, polyphosphazene, polyetheretherketone, and polyester.

The films were evaluated as pure films only, films silk-screened with an acrylic ink, and films adhered to a phenolic fiberglass substrate. Films which exhibited the highest fire-resistant properties included PEEK polyetheretharketone, Aramid polyamide, and ISO-BPE polyester.

\section{INTRODUCTION}

Sandwich panels are used extensively in wide-body aircraft interiors because of their desirable stiffness-to-weight ratio. For example, a typical wide-body aircraft has over $102 \mathrm{~m}^{2}$ of sidewall, $214 \mathrm{~m}^{2}$ of ceiling, $474 \mathrm{~m}^{2}$ of stowage bin, and $111 \mathrm{~m}^{2}$ of lavatory and galley sandwich panels.

These panels are decorated in most cases with a polyvinyl fluoride (PVF) film which is the carrier for a screen-printed ink resin and which is covered with a second, thinner transparent PVF film. Because the surface of such film in the interfor of an aircraft is large, it is important to evaluate alternative films for propertles that would reduce the risks of fire intitiation and propagation, and smoke and toxic gas evolution of these films, and thus of the whole panel.

\section{DESCRIPTION OF TEST METHODS*}

A broad range of flammability, thermochemical, and mechanical tests were conducted to fully characterise the candidate-film materials and to select the appropriate teat methods to be used in future programs. The extensive laboratory testing in the flammability area was neceseary because the Implications of laboratory-scale test results are not fully understood; that is, the correlation between small-acale and large-scale tests has not beon establiched. Five bastc properties of the materials were measurad: (1) propensity to burn, (2) smoke emisaion, (3) hast release, (4) toxic gas emission, and (5) flame propagation. In some cases, more than one test apparatus was used to maseure the same property, thus allowing a comparison of test mathods.

*The use of trade names of manufacturers in this raport does not constitute an official endorsement of such product, either expressed or implied, by the National Aeronaut Ice and Space Adminietration. 
Propensity to Burn

The propensity to burn was measured using the otandard Bunsen burner exposure teat [1] and the IIm1ting oxygen index (LOI) test [2]. The vertical 60-sec 1gnition Bunsen burner test was chosen because it is the otandard flemmabllity test required by the FA for testing wide-cabin interfor materiele. This test measures burn length and the time to extingulshment after the igniting flame is removed. The LOI test was run to determine the propensity of the materials to burn. This test exposes the specimen to an open flame in a controlled nitrogen/oxygen atmosphere and given a ranking Index that may be used to compare materials. A higher amount of $\mathrm{O}_{2}$ necessary to sustain burning Indicates a greater resistance to burning; an 1ndex rating of 100 indicates that the material would only burn in an atmosphere of $100 \% \mathrm{O}_{2}$. The rat10 of $\mathrm{N}_{2}$ to $\mathrm{O}_{2}$ is regulated; thus, concentrations of up to $100 \% \mathrm{O}_{2}$ can be obtained.

\section{Snoke Dission}

The swoke-cuission characteristics of the candidate naterials ware determined using the technique of smoke accumulation in an enclosure and by testing the materials in the National Bureau of Standards (NBS) smoke chmber [3]. The apparatus was operated over a range of Incident heat fluxes, 1.5 to $5.0 \mathrm{~W} / \mathrm{cm}^{2}$, to determine the response of the films and laminates to varlous fire environments.

Heat Release

Heat-release characteristics of the candidate materials were determined from the Ohio State University (OSU) release-rate apparatus using the technique of heat release in an exposed airstream. The apparatus was operated at an Incident heat flux of $2.5 \mathrm{~W} / \mathrm{cm}^{2}$ to determine the response of materials to this fire environment.

Toxic Gas Enfssion

Toxic gas emissions were measured in two separate teats: gas accumulation in the NBS chamber and a quantitative measure of gases from pyrolysistube decomposition. The NBS-chamber exposure represents an open-fire cond1tion where only partial (or surface) burning takes plece. The pyrolysistube exposure represents complete decomposition of the sample, since the spectimen is exposed to a $600^{\circ} \mathrm{C}$ heat source. Samples were taken in the NBS chamber using calorimatric tubes (for $\mathrm{HCN}$ and $\mathrm{NO}_{X}$ ), NaOH absorber solutions (for hallde gases), and on-11ne gas detectora (for $\mathrm{CO}$ and $\mathrm{CO}_{2}$ ). The NaOH solutions were analyzed ueing specific Ion electrodes. Samples were taken of the pyrolysis-tube effluent uaing NaOH absorber solutions. The difference between the two sample techniques was that the gaees from the NBS chamber were taken as a grab sample and results were expressed as a concentration (parts per million) of the gas in the accumulation chabber, whereas gases from the pyrolysis tube were absorbed during the entire test and results were expressed as a total yleld (1.e, milligrame of gas par gram of eample).

\section{Flame Propagation}

The flame-propagation propertiee were menoured on the ASTH E162 flameopread apparatue [4], wh1ch meagures the ourface flamability characteriatica 


\section{ORIGINAL PAGE is \\ OF POOR QUALITY}

of materials. This method of measuring material surface flamability uses a radiant heat source in front of which an inclined apecimen of the maturial is placed. The orlentation of the epecimen 1o such that 1 gnition is forced near Its upper edge and the flame front progreases downward. A ileme-sprand index $\left(I_{s}\right)$ was calculated by combining two factora: one factor derived from the rate of progress of the flame front (1gnition properties) and another factor relating to the rate of heat liberation by the aterial being teated.

Thermochemical Testo

Both differential scanning calorimetry (DSC) and thermogravimetric analysis (TGA) thermochemical tests were run to determine (1) the decomponition rates of the films, (2) the exotherm/endotherm of the materials as they ware decomposing, and (3) their velght $108 s$. The materials with high exotherms were considered undesirable because of their potential contribution to a fire. Materials with a high waight lose at temperatures below $260^{\circ} \mathrm{C}$ were undealrable because the gases given off at these low temperatures would contribute ignitable fuel to a fire.

Mechanical Tests

Mechanical-property tests were run on the candidate f1lms to detarmine their bond strength, wear resistance, and tensile properties. Bond strengthe were measured by determining the peel strength between top films and substrate films, and between substrate films and fiberglass-preimpregnated films. number of cycles required to penetrate the film laminate. Tensile properties were measured by calculating the elongation, tensile strength, and breaking factor of the materials.

Additional Tests

Tests were run on the decorative films to determine their resistance to staining and to ultraviolet (UV) 11ght degradation, and their Ink adhesion/ flexibility, dimensional stability, and texture attainability. All of these tests relate to the aesthetics of the decorative film - a very important consideration. Color stability was measured by monitoring color shifts of the fllms after exposure to UV light. Ink adhesion/flexibility was measured by screen-printing the candidewe with the currently used acrylic Ink syotem and determining the bonding, flexibility, and coverage characteristics. Dimensional stability was measured by calculating the change in sise of a specimen following its exposure to a temperature of approximately $132^{\circ} \mathrm{C}$ for approximately $10 \mathrm{~min}$.

The selection criteria and test methods used for oveluating the filmo are shown in Tables 1 and 2 .

\section{DESCRIPTION OF MATERIALS}

New materials were selected to teat their fire resistance through burning more slowly, anitting lese omoke, cultelng lese toxic gas, and/or retarding the flame spread during a Elre exponure. The candidate decorative films tested are shemn in Table 3 and Included polyvinylidene fluoride, PVT (FM Tedlar), three polyesters (ISO-BPE, Molinex 334, and Permacare IV 2693), polyphosphasene, polybensimidasole, two polyimides (Kapton and DAPI-BPTA). 
polyparabanic actd, acrylic, polycarbonate, polyethersulfone, polysulfone, polyphenyisulfone, Ionomer, two polyamides (Nomex and Aramid Film A), and polyetheretherketone. Some of these films were color plgmented, others were naturally colored, and still others were clear. Some were tested as candidates for a top protective film, some for a substrate, and others for both applications. However, all were compared to the baseilne PVF film (No. 1) used by aircraft manufacturers today. During the evaluation testing, films were first considered Individually and then in combination (1.e., top film and substrate film laminated together). Testing of candidate films in confunction with a sandwich-panel substrate was unnecessary; instead, combina-. tions (film larinates) were evaluated bonded to a three-ply phenolic/ fiberglass comp. 3ite.

\section{Baseline System}

Two basic types of decorative sandwich panels are currently in use by aircraft companies. The f1rst type consists of a precured blank panel ontō which is bonded a decorative polyvinyl chloride outer layer. The materials used in the sandwich skins are normally flame-retarded (FR) epoxy/fiberglass (e.g., halogenated). The honeycomb core was phenolic/Kraft paper before 1970 , but has since been changed to phenolic/polyamide paper. The second type of decorative sandwich panel considered for this study consists of an integral decorative skin that replaces the polyvinyl chloride and also forms the structural member of the sandwich panel. The decorative layer in this type of construction is printed or silk-screened PVF. Like the material used in the first type, the face sheets of this type of panel are FR epoxy/ fiberglass and the honeycomb core is phenolic/polyamide. The epoxy/fiberglassface-sheet and phenolic/polyamide-honeycomb-core portions of the sandwich panel were studied previously [5], for flammability, smoke, and toxicity. comparisons. Therefore, only the phenolic-fiberglass decorative layer was considered in this study.

\section{RESULTS AND DISCUSSION}

The films were evaluated in a series of tests documented in Tables 1 and 2. The first screening involved the evaluation of neat films only; the second screening involved the evaluation of film laminates consisting of a top film of clear $0.025-\mathrm{mm}$ PVF bonded to a substrate $0.051-\mathrm{mm}$ candidate f1lm which had been screen-printed with acrylic ink; and the third screening involved film laminates consisting of (1) 0.025-m PVF bonded to a $0.051-\mathrm{mm}$ candidate film, (2) $0.025-\mathrm{mm}$ PVF bonded to a 0.051 -m candidace $\mathrm{fll}$ m bonded to a three-ply phenolic fiberglass with an adhesive, and (3) $0.025-\mathrm{mm}$ PVF bonded to a $0.051-\mathrm{mm}$ candidate film bonded to a single-ply phenolic fiberglass with no adhesive.

\section{First Screening}

Individual films were tested for LOS, smoke miseion, toxicity, tunsile strength, and elongation. The LOI data for the films are shown In Figure 1. LOI values rianged from 19.0 for polymethylpentene (F1lm No. 14) to 43.1 for Kapton polyimide (Film No. 4). Currently used PVFe have LOI velues below 30; therefore those materlal exhibiting values above 30 would possess a lesser tendency to burn than the currently used PVFs. While these LOI data 
are not conclusions in themselves, they do indicate a general ranking of the films. These data, combined with other flammabllity properties, can give an overall ranking of the films.

The smoke-emission characteriatics of the films were neasured by testing individual films in the NBS smoke chamber, which is a closed, noncirculating sccumulation compartment. The apparatue was oparated at $2.5 \mathrm{w} / \mathrm{cm}^{2}$ for $4.0 \mathrm{mIn}$ in a flaming mode (see Figure 2). In general, polyphosphazene, polyesters, and acrylics produced more smoke than most of the other films. This is probably due to the presence of fire-retardant additives and/or inherent properties of the polymers. Polyimides, polyamides, polybenzimidazole, polyparabanic acids, polycarbonates; polysulfones, and 1onomers produced less smoke than the currently used PVFs. These materlals are generally more thermally stable than PVF. The polyvinylidene fluorides produced about the same amount of smoke as the currently used PVFs.

Toxic gas evolution was measured by sampling the gases collected in the NBS smoke chamber during the smoke-emission test. Figure 3 shows the $C O$ and HF evolution from the films. Gas samples tested in the NBS chamber gave off only small amounts of $\mathrm{HCN}, \mathrm{NO}_{\mathrm{X}}$, and $\mathrm{HCl}$, and a reiatively small amount of $\mathrm{CO}$. As expected, the baseline PVF evolved the most HF. FM PVF and polyvinylidene fluoride showed lower HF evolution, when compared with the baseline PVF. The absence of toxic gas emission data on many of the films 18 due to the unavallablitity of material and/or no measurement being made. For Inatance, HF evolution was not measured for polycarbonate since it contains no HF-producing material.

Mechanical strengths of the candidate films were determined by measuring the tensile properties in the longitudinal direction. Measurements were made at fallure and at yleld. Figure 4 represents the ultimate-elongation test results. Elongation was determined to check the ability of the films to be textured and formed to complex shapes. Although no precise elongation and tensile-strength requirements can be established, it is desirable to have a minimum of 20 to $30 \%$ elongation and approximately the same tensile strength as the currently used PVF.

It can be seen in Figure 4 that polyetheretherketone (Film No. 24) and ionomer (F11m No. 16) have approximately the same ultimate elongation as the baseline PVF (Film No. 1), making them excellent candidates for decorative films.

Second Sireening

The second screening involved the testing of the $0.025-\mathrm{mm}$ PVF bonded to the candidate films which had been screen-printed with ink. Ink-compatibility, adhesion and flexibility, texture-attainability, UV-stability, and shrinkage tests were run on the candidate fllms remaining after completion of the first flammability screening. Ink compatibility was determined by silk-screen printing of a white acrylic ink on the substrate film and subsequently observing for any detrimental effects, ouch as the ability of the Ink to cover the substrate film's color. Adhesion and flexibllity ware determined on the screen-printed semples by tightly rolling the samples around a 13-min wooden dowel with the screen-printed face positioned Inward. This was ropeated 10 times and observations were made for cracking, flaking, and separation of the Ink film.

Shrinkage was determined by exposing 15.2 - by $15.2-\mathrm{cm}$ samples to a temperature of $132^{\circ} \mathrm{C}$ for $10 \mathrm{~min}$ in a circulating-air oven. The samples were measured in the transverse direction both before and after the 10-min exposure. 
Only the 1onomer (F1lm No. 16) wat dropped from further evaluat1on besed on shrinkage test resulte. Ultraviolet stabllity was detsrmined by the procedure descr1bed in ASM G27-70 [6]. The stabllity of the test specimane, which nexoured 6.4 by $15.2 \mathrm{~cm}$, was determined at the and of a 25-hr vV-exposure pertod. Filmo which ware unatable under UV exposure included Aramid polyomide (F1lm No. 11), polyetheraulfone (F1lm No. 13), and polyvinglidene fluoride (F1ln No. 17). These materials efther discolored or lost their machanteal propertles after the UV exposure.

\section{Final Testing}

Final testing was conducted on three types of laminates, as shown in Table 2, which represent varlous stages of construction of a typical andrich panel (FIgure 5). The film laminates which remained as candidates after the first and second screening are shown in Table 4. These film laminatne were tested for LOI, HF evolution, peel and tensile strength, and ultimate elongation. The LOI results are shown in Figure 6. The LOI values ranged from 24.2 for the ISO-BPE polyester film laminate (Film No. 6) to 53.9 for the polyvinylidene fluoride film laminate (Film No. 17). Laminates of Fluorex HT-I exh1bited the highest LOI of 52, and the others fell into a range of about 24 to 35 . The film laminates were pyrolized in a round tube in a furnace, and the HF evolution was determined. As expected, the highest ar evolution was from the baseline PVF (Film No. 1) followed by the FM PVF (FIIm No. 2) and polyvinylidene fluoride. Complete test results are ohown in Figure 7. Peel-strength (top film-substrate film interface) tests were performed and the regulis are shown in Figure 8. The peel strength was determined to evaluate the bond strengths between the top and substrate films. The ISO-BPE polyester film showed the lowest peel strength, and the PEEK polyetheretherketone film (F1lm No. 24) showed comparable peel and tensile properties to the baseline PVF. The yield strength and the ultimate elongation of the film laminates were determined and are shown in Figure 9 . It can be seen that the PEEK polyetheretherketone film has equivalent ultimate elongation and higher yield strength than the baseline PVF f1lm. The ISO-BPE polyester film was extremely brittle and therefore was not sultable for complex panel shapes. Specimens consisting of a film laminate and a three-ply phenolic/fiberglass composite bonded together with a pressure-senaltive silicone adhesive were tested. The flame-spread characieristics of the f1lms we-e measured to determine their contribution to the surface fire propagation properties of a sandwich panel and the test results are hown in F1gure 10. All of the laminates with fluorine-containing subatrate films exhibited approximately equal flame-spread characterlatics, whereas the ISO-BPE polyester (Film No. 6) showed increased $I_{8}$ values compared with the others. The baseline PVF had lower Is value because the film peeled avay from the front surface of the fleme, thus exposing the phenolic/ flberglass subetrate, which has a lower flame-spread value. The smoke aniseion of the same laminates is shown in Figure 11, and the toxic gan andosion of these laninates is shown in Figure 12. As expected, high bip evolut on is shown in the $M$ PVF and polyvinylidene fluoride laminates.

Tt o heat-release data for the leminates is shown in Figure 13. Since the was of the filme was Insignificant compared with the wase of the phenolic fiberglase, seall differences vere observed between the leminates containing the filme, and the significance of the data is quastionable.

SImilar flamability teats were conducted with the fllma bonded to a single ply of phenolic fiberglase. The flame-spread data for these lantnates 
are shown in F1gure 14. The lowest flame spread was exhiblted by the PEZK polyetheretherketone laminate (Film No. 24) and the highest flame spread was exhibited by the ISO-BPE polyester 1aminate ( $F \pm 1 m$ No. 6). In the case of the baseline PVF (Film No. 1), as soon as the flame bagins, the film burne and shrinks avay from the flame front.

The vertical FAA flamability test was conducted on these laminates and the test results are shown in F1gure 15. All of the armples vere ecceptable according to FAA standarda.

The smoke enission of these laminates was determined at three heat fluxes: $1.5 \mathrm{~W} / \mathrm{cm}^{2}, 2.5 \mathrm{~W} / \mathrm{cm}^{2}$ and $5.0 \mathrm{~W} / \mathrm{cm}^{2}$. The test results are chown in Figure 16. The $C O$ and tr evolutions are also shown as a function of heat flux in Figures 17 and 18. The PEEK polyetheretherketone laminate (FIIm No. 24) had the lowest smoke evolution at all heat-flux ranges.

\section{CONCLUSIONS}

The propensity to burn and the toxic gas emission, especially uf, of panels can be significantly lowered by using polyetheretherketone as a substrate film suitable for screen printing ink. The relative ranking of the films based on these laboratory studies is shown in Table 5. Potential problems such as clarity, gelation spots in the film, and sultable width will have to be resolved before this film can be developed to its full potential. The Aramid polyamide film had good fire-resistant properties but had low elongation and was UV-unstable. The ISO-BPE polyester also had a very IOW elongation and was extremely brittle. All of the fluorinated films (baseline PVF, FM PVF, and polyvinylidene fluoride) exhibited very high HF evolution.

\section{ACKNOWLEDGMENTS}

The author wishes to acknowledge the Boelng Commercial Alrplane Company for conducting many of the tests described in this paper. Complete test data are given in Reference 7 .

$$
\begin{aligned}
& \text { URIGINAL PAGE IS } \\
& \text { OF POOR QUALITY }
\end{aligned}
$$






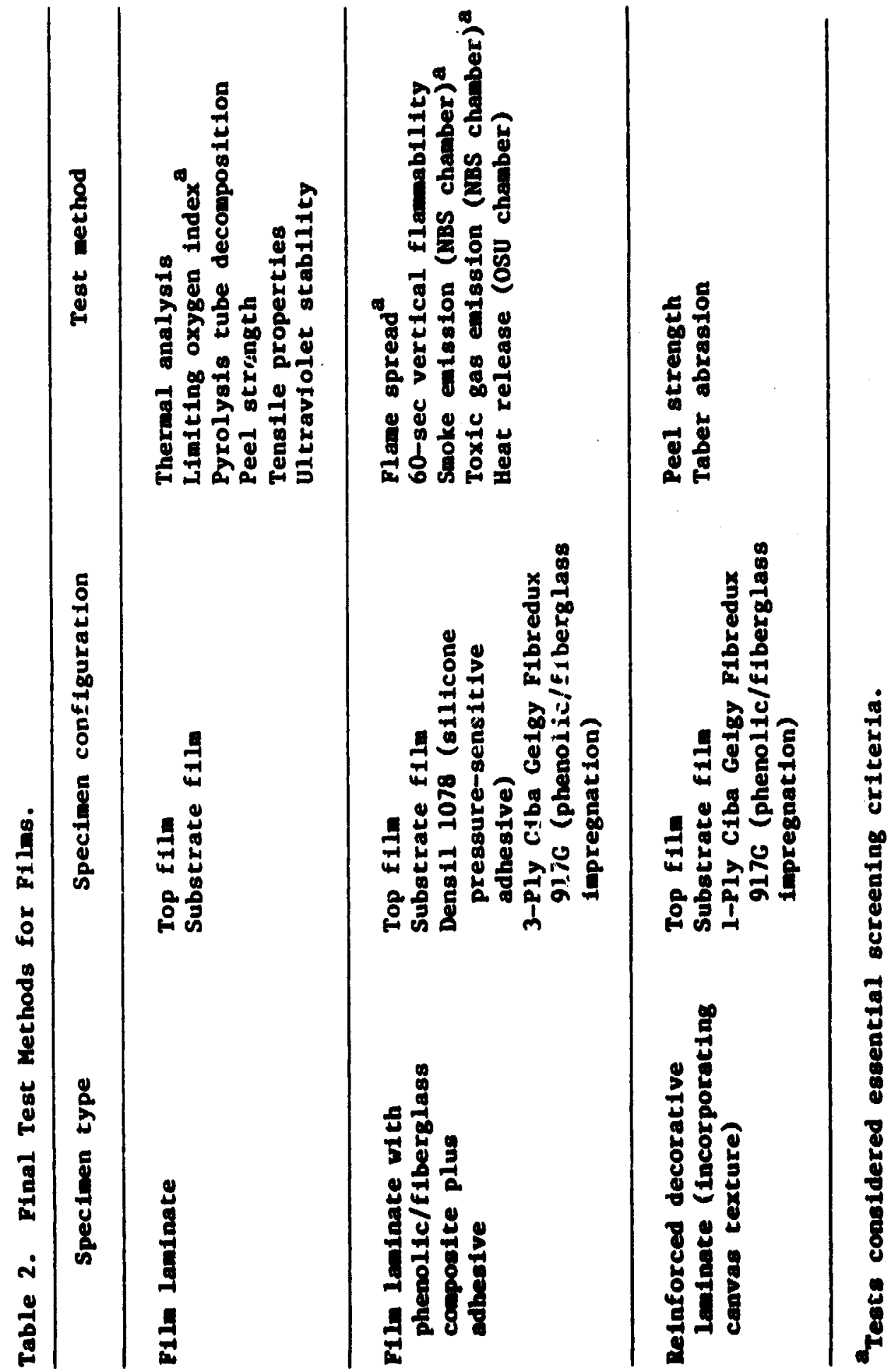


ORICINAL PACE IA
OF POOR QUALITY

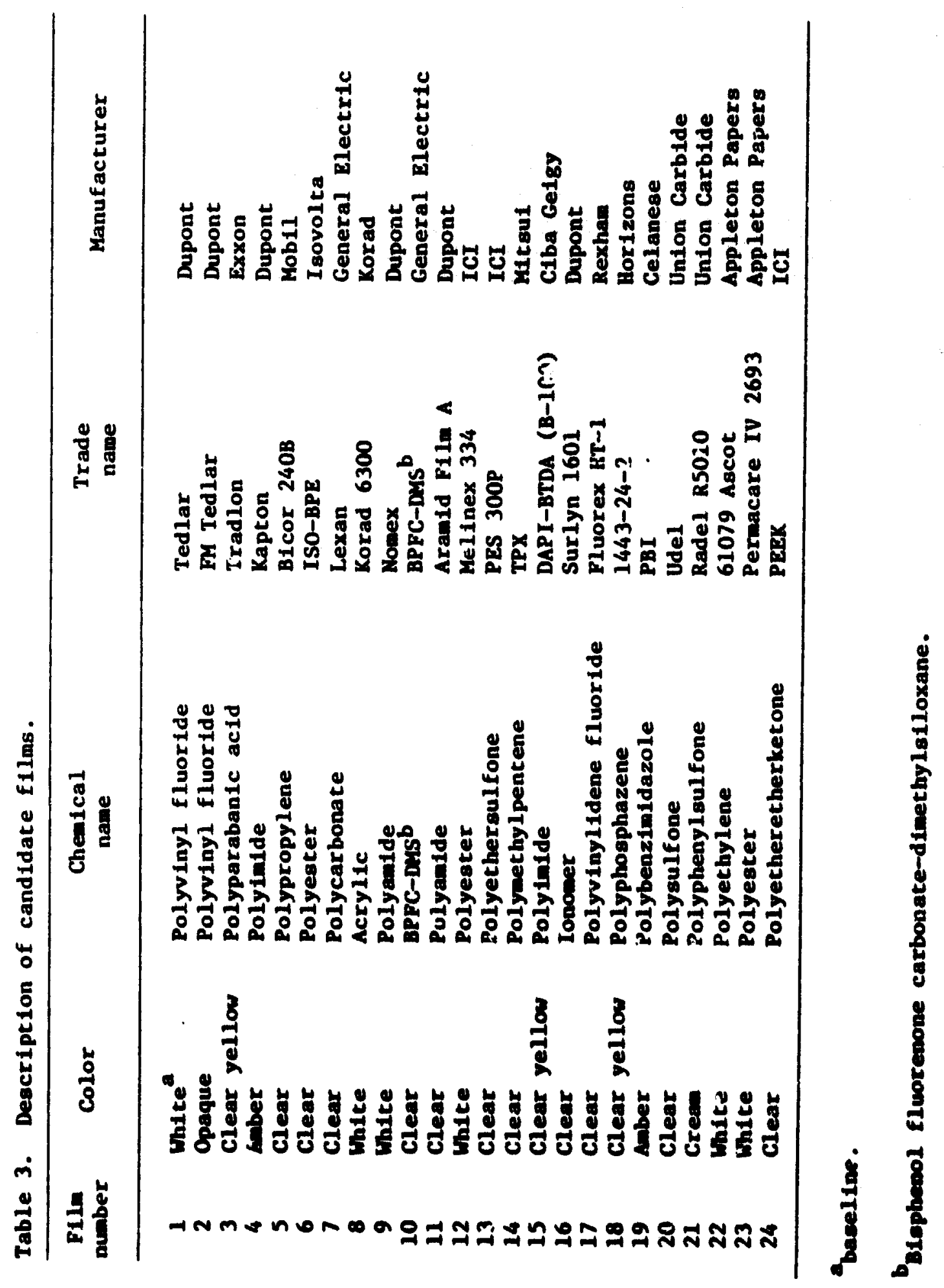



Table 5. Relative ranktas of s11ns."

\begin{tabular}{|c|c|c|}
\hline Substrate t11m Vo." & Subotrate t11a, $0.031=$ & Problenes \\
\hline $\begin{array}{r}24 \\
11 \\
6 \\
17\end{array}$ & $\begin{array}{l}\text { Polyethylethylketone } \\
\text { Aremid polycalde } \\
\text { Iso/DPE polyeter } \\
\text { Polyvinylidene tluoride }\end{array}$ & 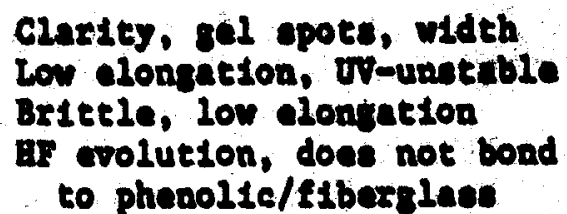 \\
\hline $\begin{array}{l}2 \\
1\end{array}$ & $\begin{array}{l}\text { DX PVF } \\
\text { Baceline PW }\end{array}$ & $\begin{array}{l}\text { if colution } \\
\text { in crolution }\end{array}$ \\
\hline
\end{tabular}

ainal relative ranking of film leminates wa based on mintmu phyelcal properties and on LOI, Elems opreed, emoke enteston, and toxtetity.

b The wost fire-resiotent filme are Lised flret.

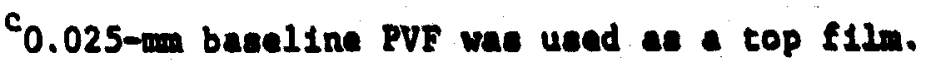

ORIGINAL PAGE is

OF POOR QUALITY 
F1gure 1. The LOI test results of films frov the first screaning. Io data avallable for Film No. 24.

Figure 2. Snoke-enlasion test results of films from the first screening. Filmo vere tested in the NBS Chaber at $2.5 \mathrm{w} / \mathrm{cm}^{2}$. No data avatlable for Film No. 16.

Figure 3. Results of toxic gas emisston tests of flins from the first screening. Films were tested in the NBS Chamber at $2.5 \mathrm{~W} / \mathrm{cm}^{2}$. See Table 2 for descriptions of films. No dat:a available for Film No. 20.

Figure 4. Ultimate-elongation test results of filmo from the firet screaning. Films were measured in the longitudinal diz nctict. No data avallable for F1Im Nos. 16, 18, and 19 .

Figure 5. A typical phenolic sandwich pangi:

Figure 6. The LOI test results of films from the finel testing.

Figure 7. The HF evolution of films from the final testing.

Figure 8. Peel and tensile strengths of films from the final testing.

Figure 9. Yield strength and ultimate-elongation test results of films from the final testing.

Figure 10. The $I_{s}$ test results of films from the third screening. All film laminates were bonded to a three-ply phenolic/fiberglass composite and a pressure-sensitive silicone adhesive.

Figure 11. Smoke-emission test results of films frow the thitd screening. Films were tested in the NBS Chamber at $2.5 \mathrm{~W} / \mathrm{cm}^{2}$. All film laminates were bunded to a three-ply phenolic/fiberglass composite and a presaure-sensitive silicone adhesive.

Figure 12. Results of toxic gas emiseion tests of films from the third screening. Films were tested in the NBS Chamber at $2.5 \mathrm{~W} / \mathrm{cm}^{2}$ All $\mathrm{film}$ laminates were bonded to a three-ply phenolic/fiberglase composite and a pressure-sensitive silicone adhesive.

Figure 13. Results of hea:-release teats of filing from the third screening. Films were tested in ths NBS Chamber at $2.5 \mathrm{~W} / \mathrm{cm}^{2}$. All $\mathrm{fllm}$ laminates ware bonded to a three-ply phenolic/fiberglase composite and aressura-sensitive silicone adhesive.

Figure 14. The $I_{g}$ resulta of film from the final testing. All Ellm laminates were bonded to a angle-ply phenolic/fiberglans composite. 
Figure 15. Test results of FAM flammability teots of filme from the final testing. All film laminates were bonded to a single-ply phenolic/fiberglace composite.

Figure 16. Smoke-emisalon test results of films from the final testing. Films were teated in the NBS Chamber. All film laminates were bonded to a single-ply phenolic/fibergless composte.

Figure 17. Results of CO colssion tests of fllms from the finel testing. Films were tested in the NBS Chember. All film laminates were bonded to a single-ply phenolic/fiberglass composite.

Figure 18. Results of uF enission tests of films from the final testing. Films were tested in the NBS Chamber. All film laminates vere bonded to a single-ply phenolic/fiberglass composite.

ORIGINAL PAGE IS

OF POOR QUALITY 

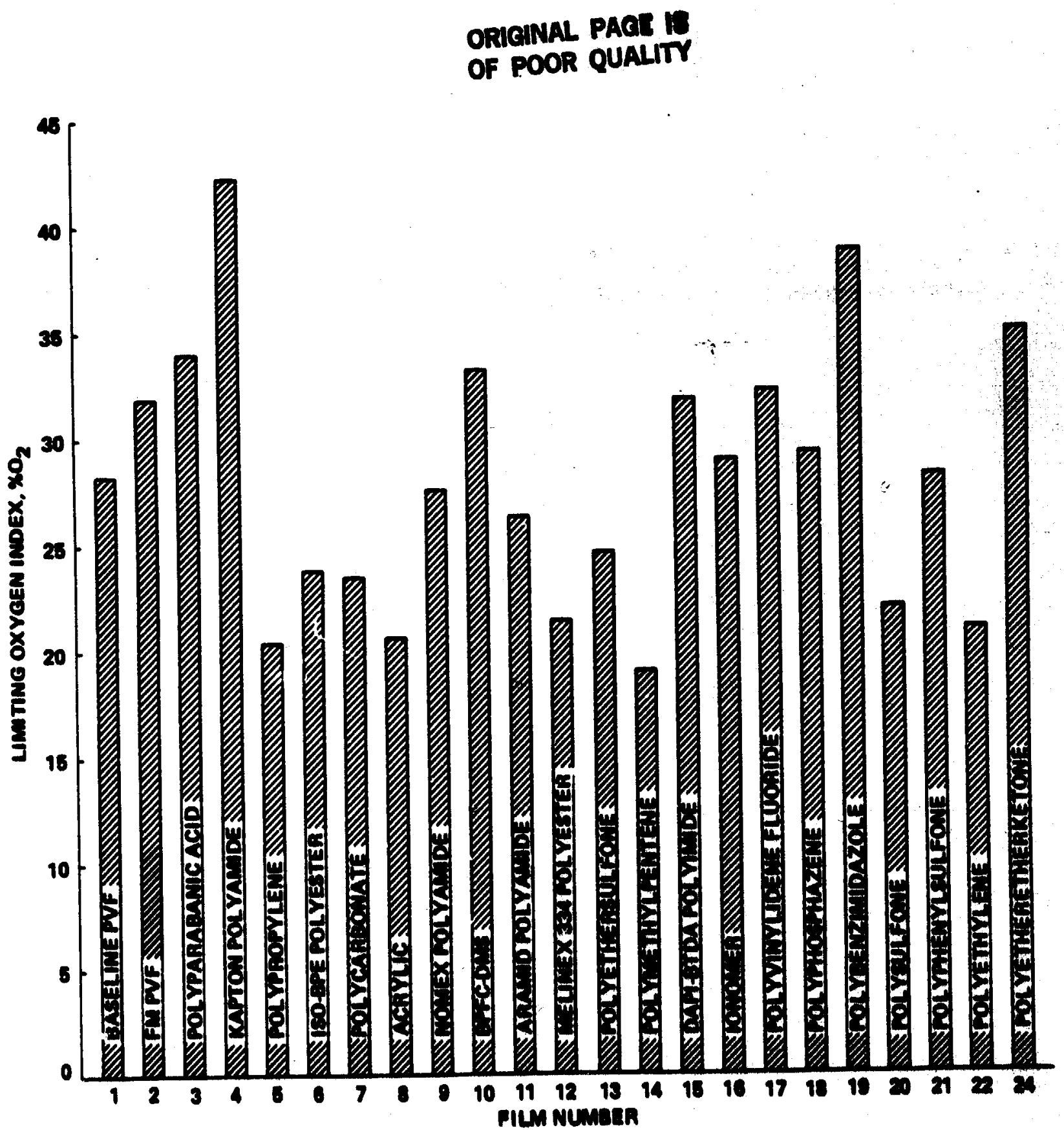

F18. 1 

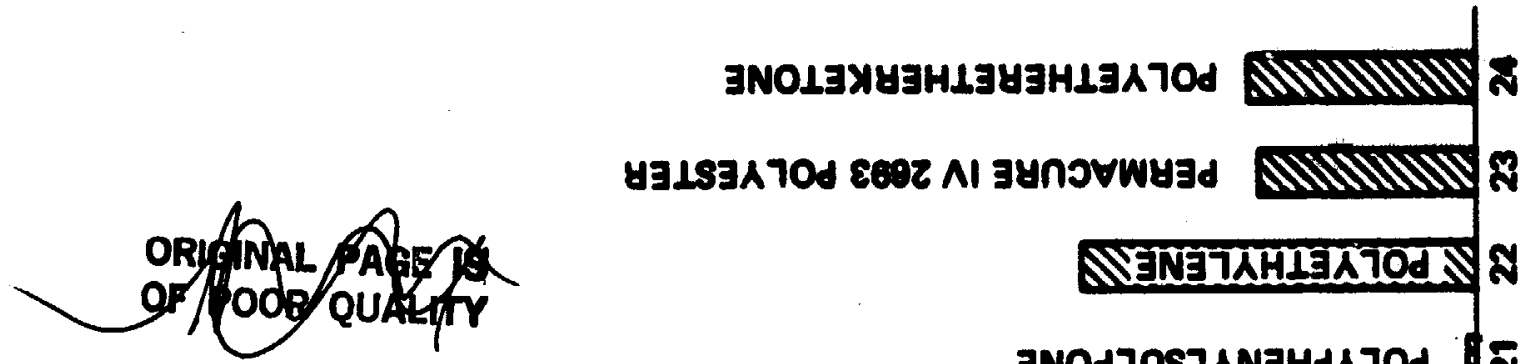

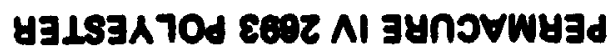

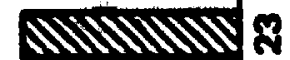

NINETAHLSXTOdN N

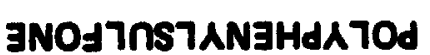
$\sqrt{2}$

3NOJ7nSATOd /8 3าOzจaIWIZN384 70d

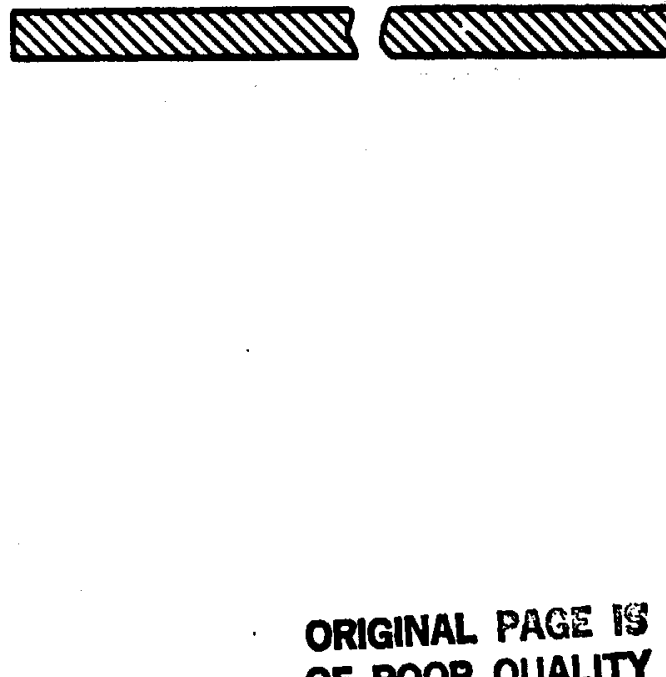

OF POOR QUALITY

30

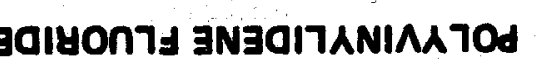

30IWIA TOd $\forall 0 \perp 8-1 d \forall O$

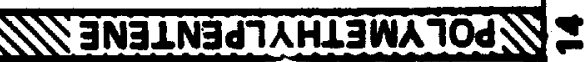

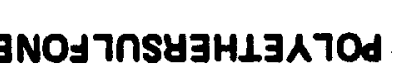

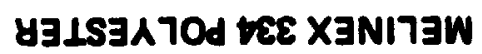

AIII

zaıw

$\left\{\begin{array}{l}2 \frac{0}{4} \\ =\frac{0}{5} \\ =\frac{3}{2}\end{array}\right.$

N

$\infty$

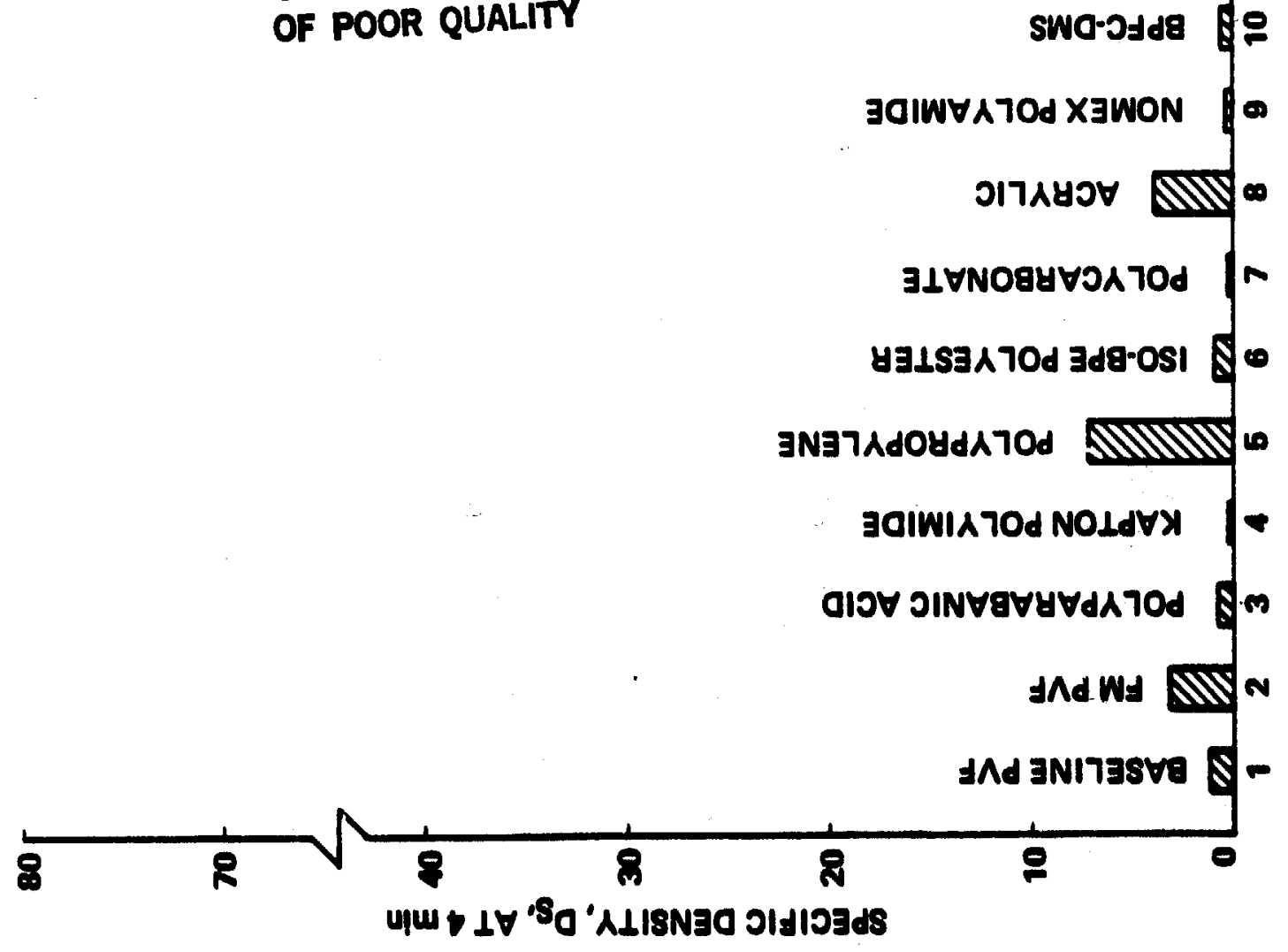





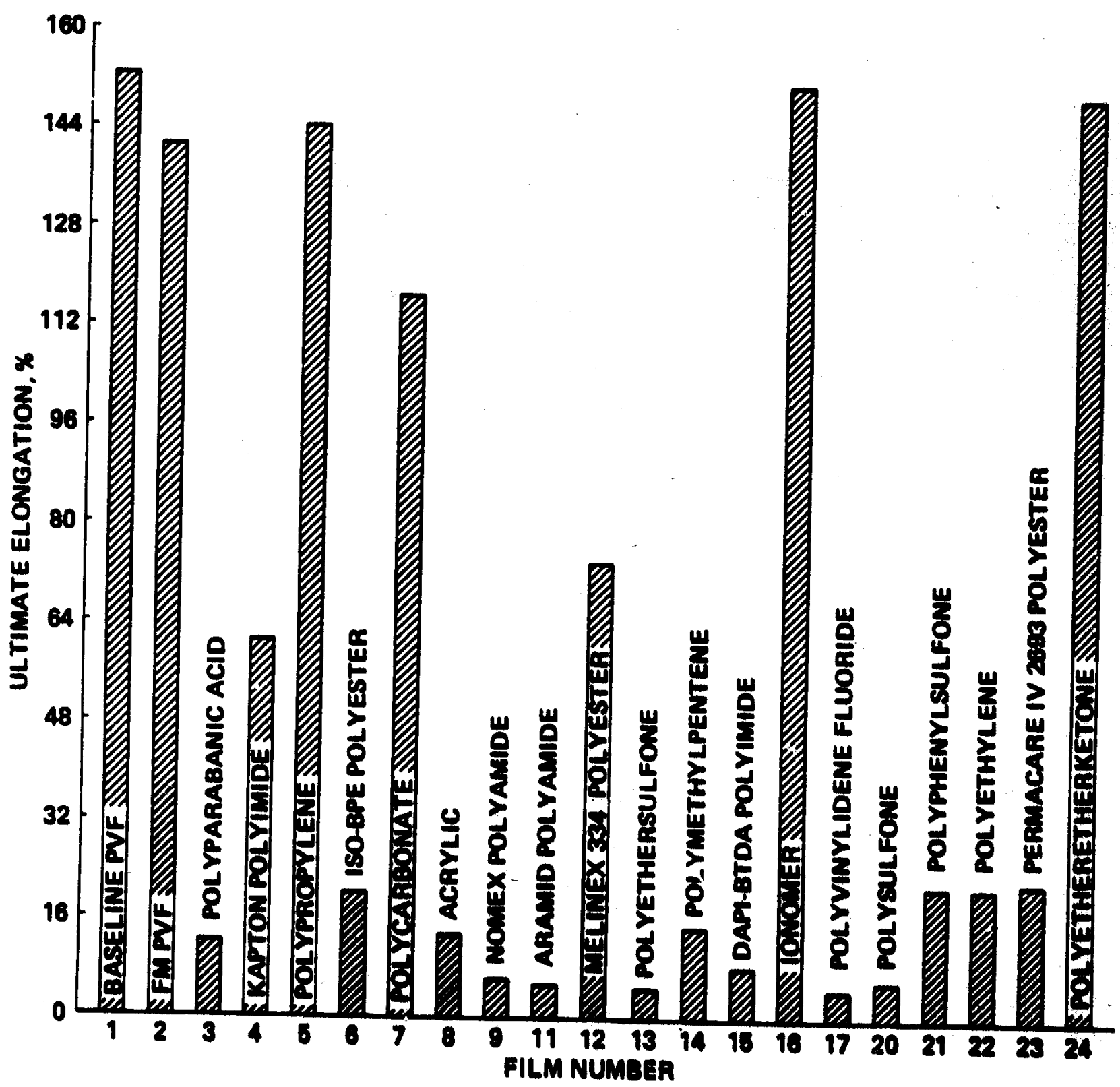

F18. 4 
ORIGINAL PACE IS
OF POOR QUALITY

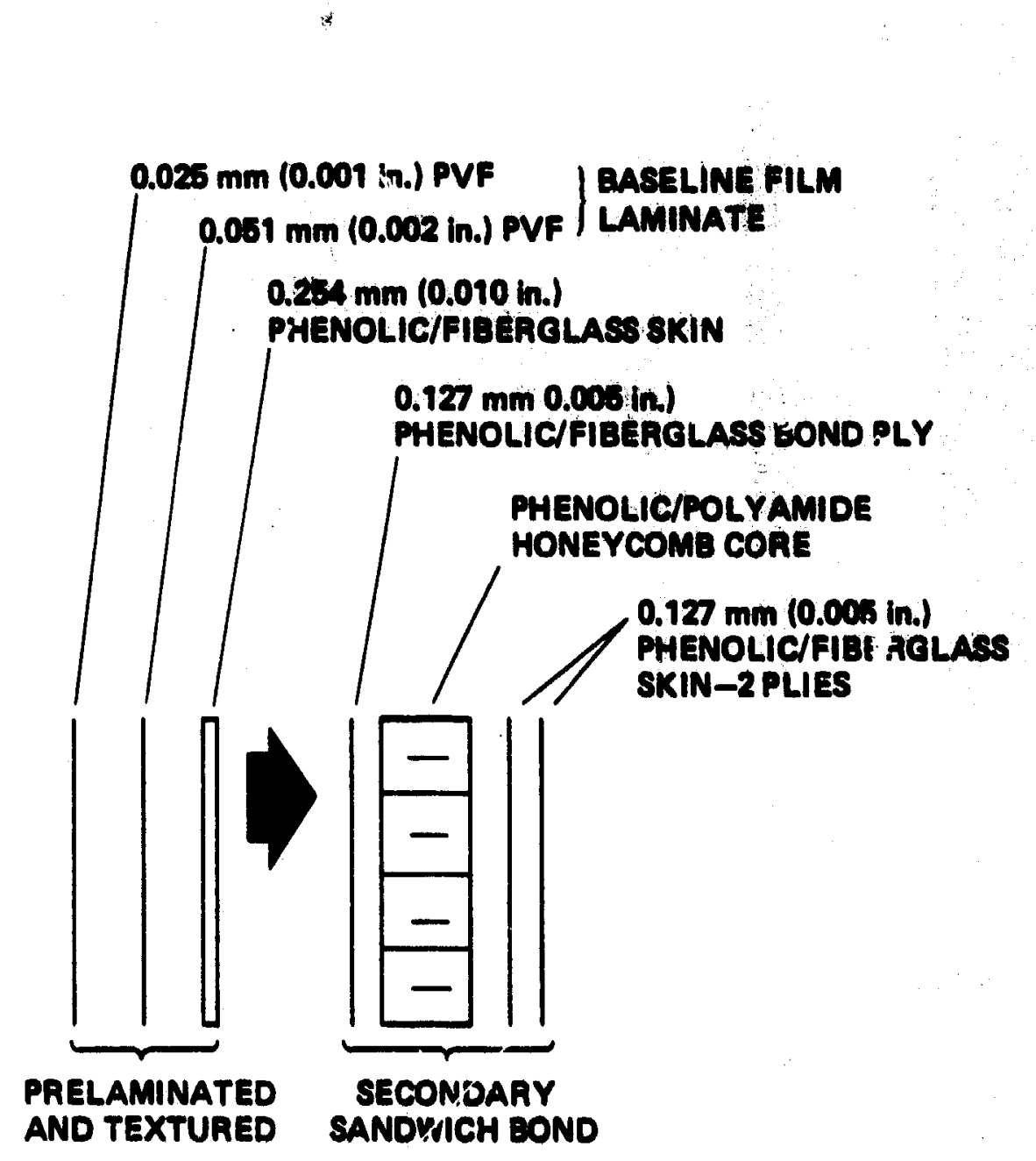

F18. 5 



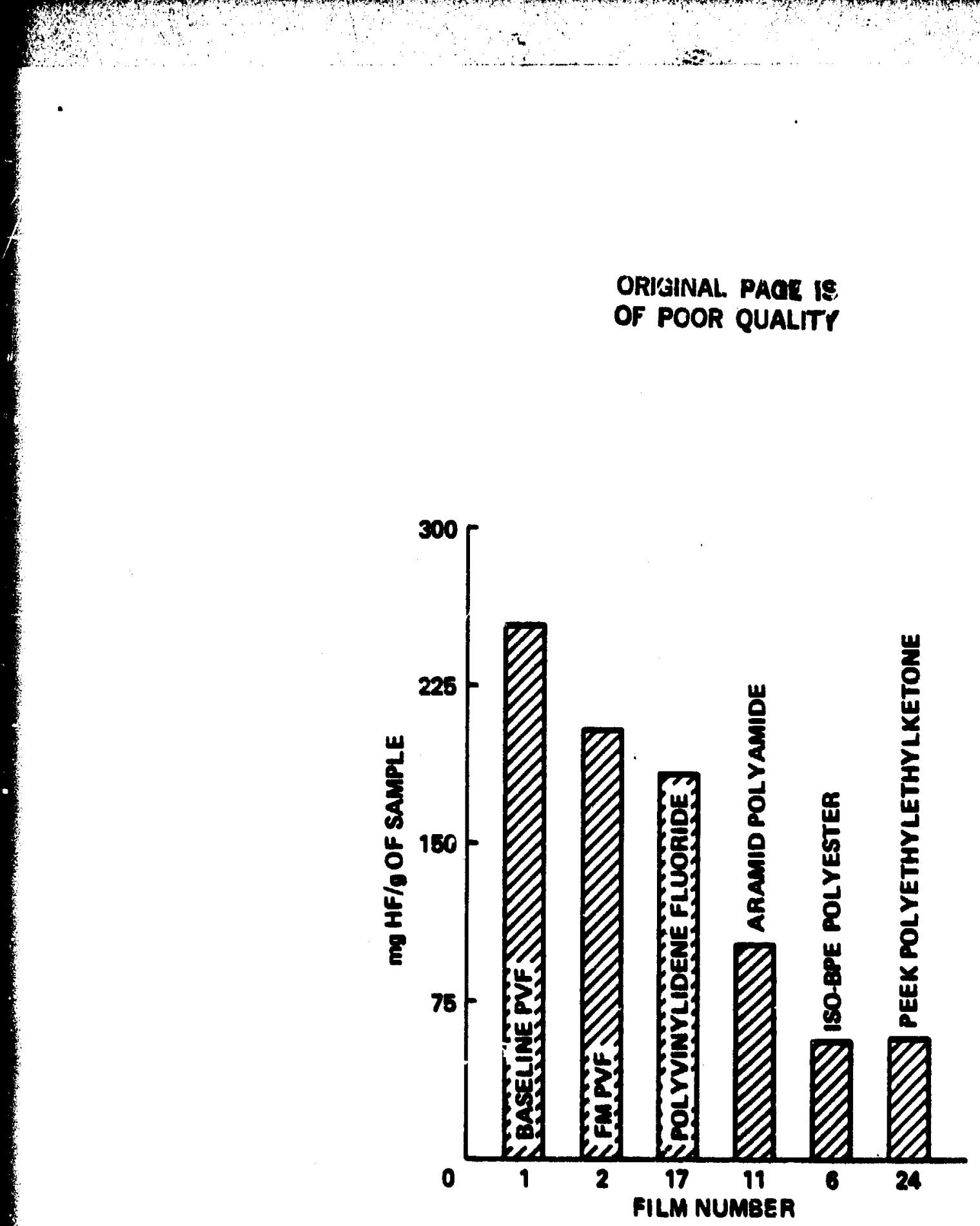

F18. 7 
original page is

OF POOR QUALITY

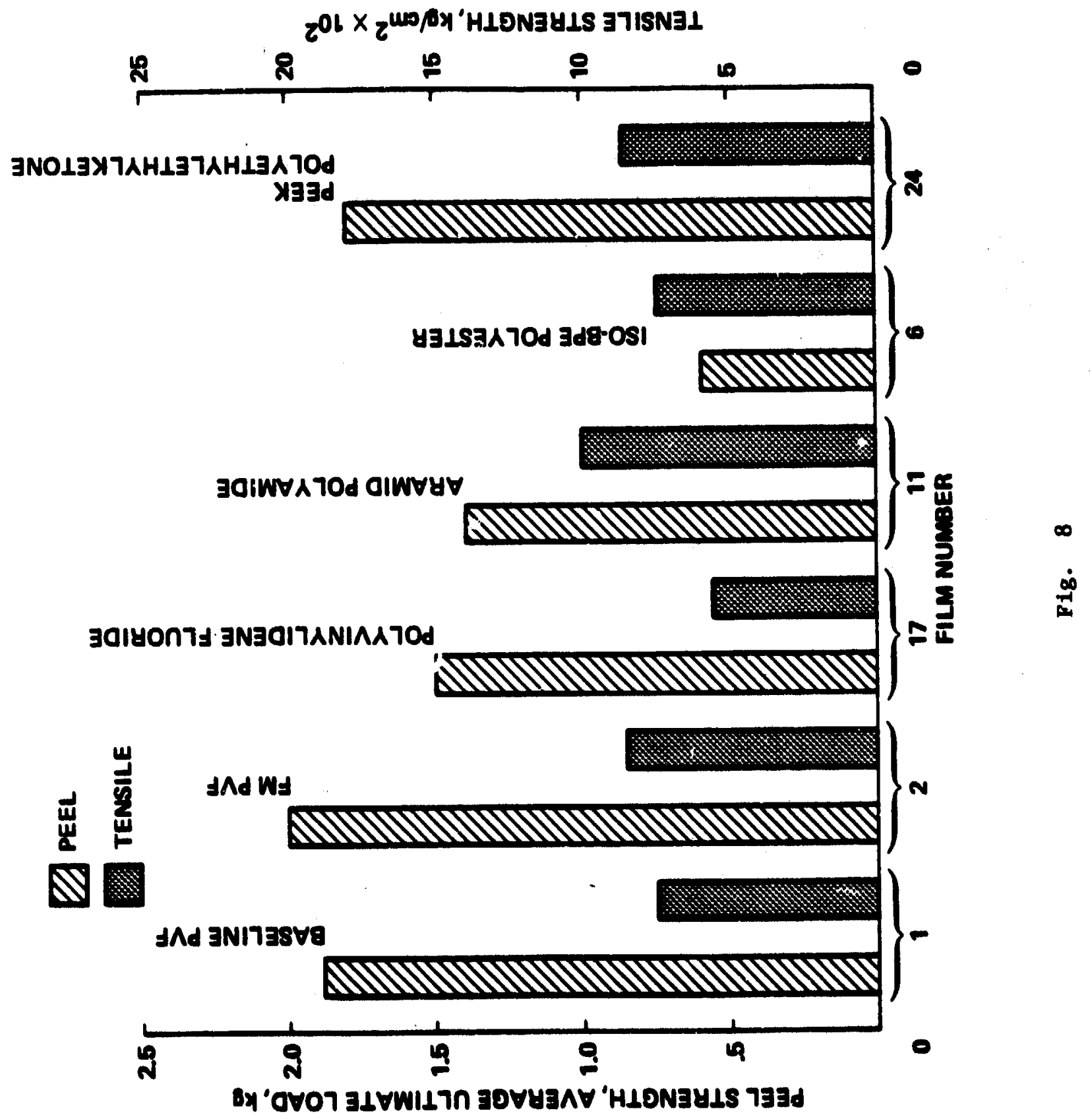


ORIGINAL PACE R:

OF POOR QUALITY

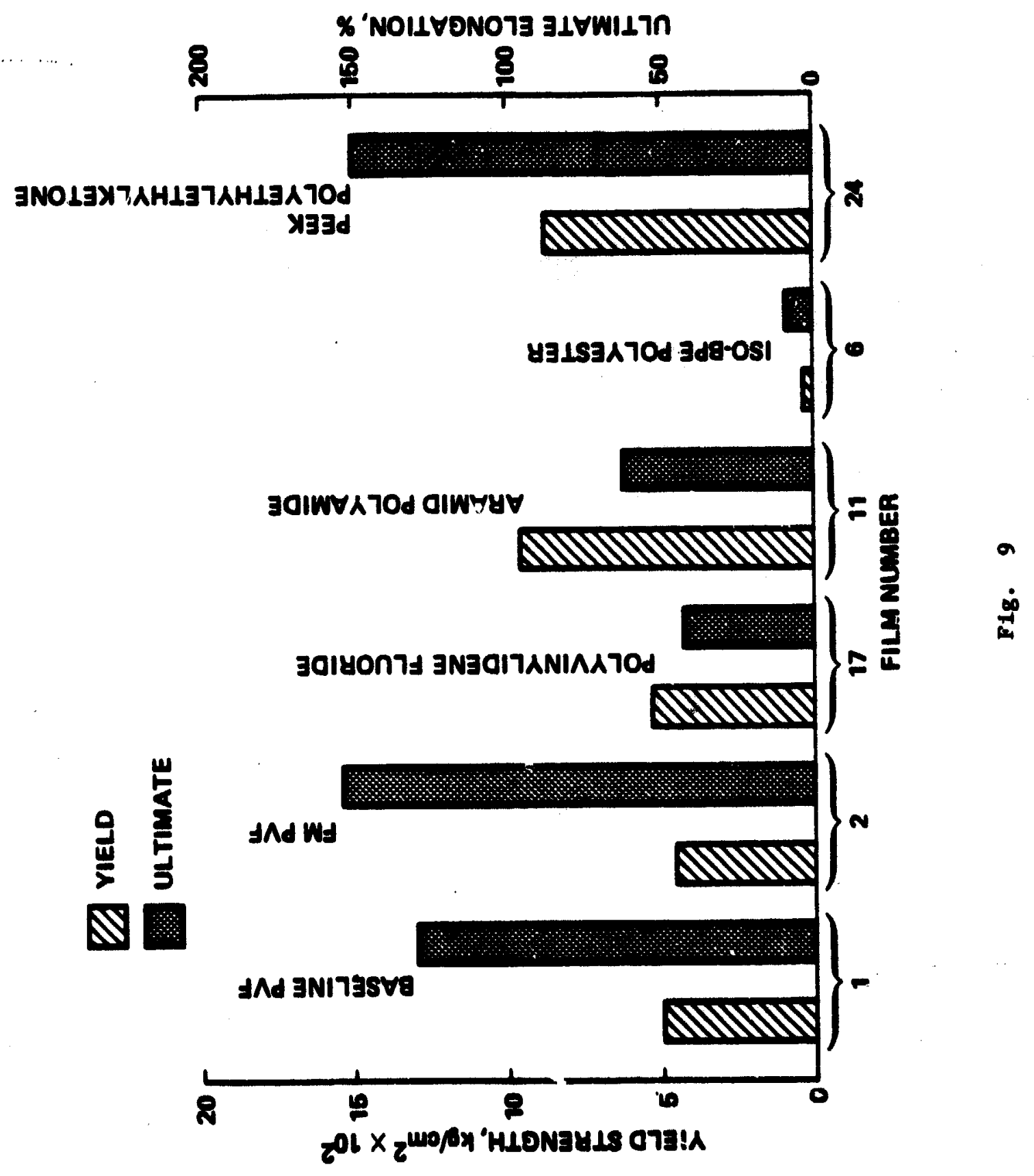




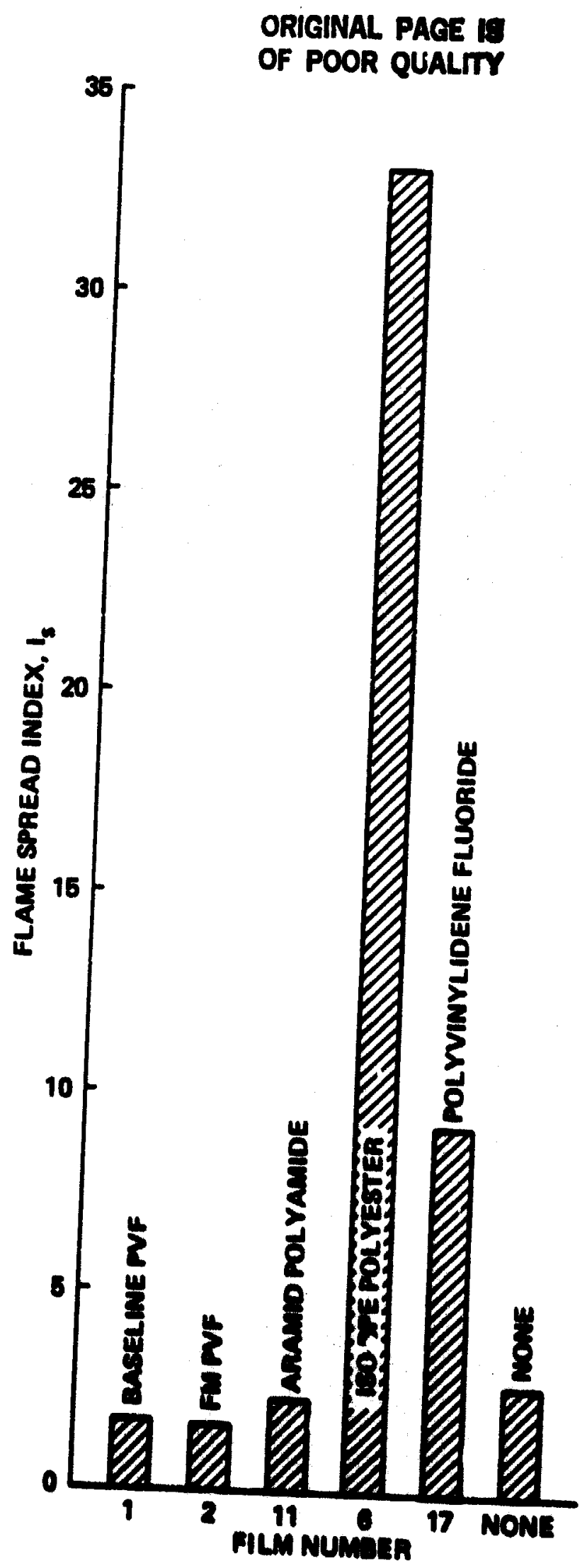

F18. 10 


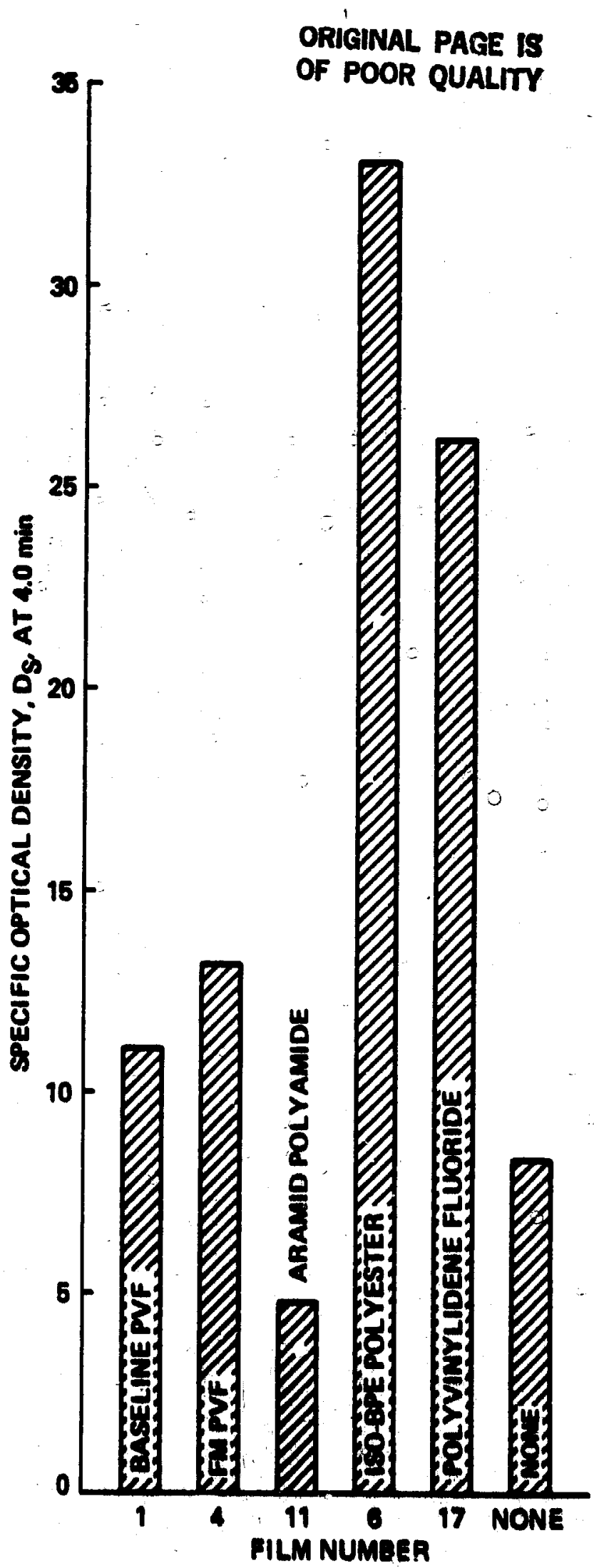

F18. 11 


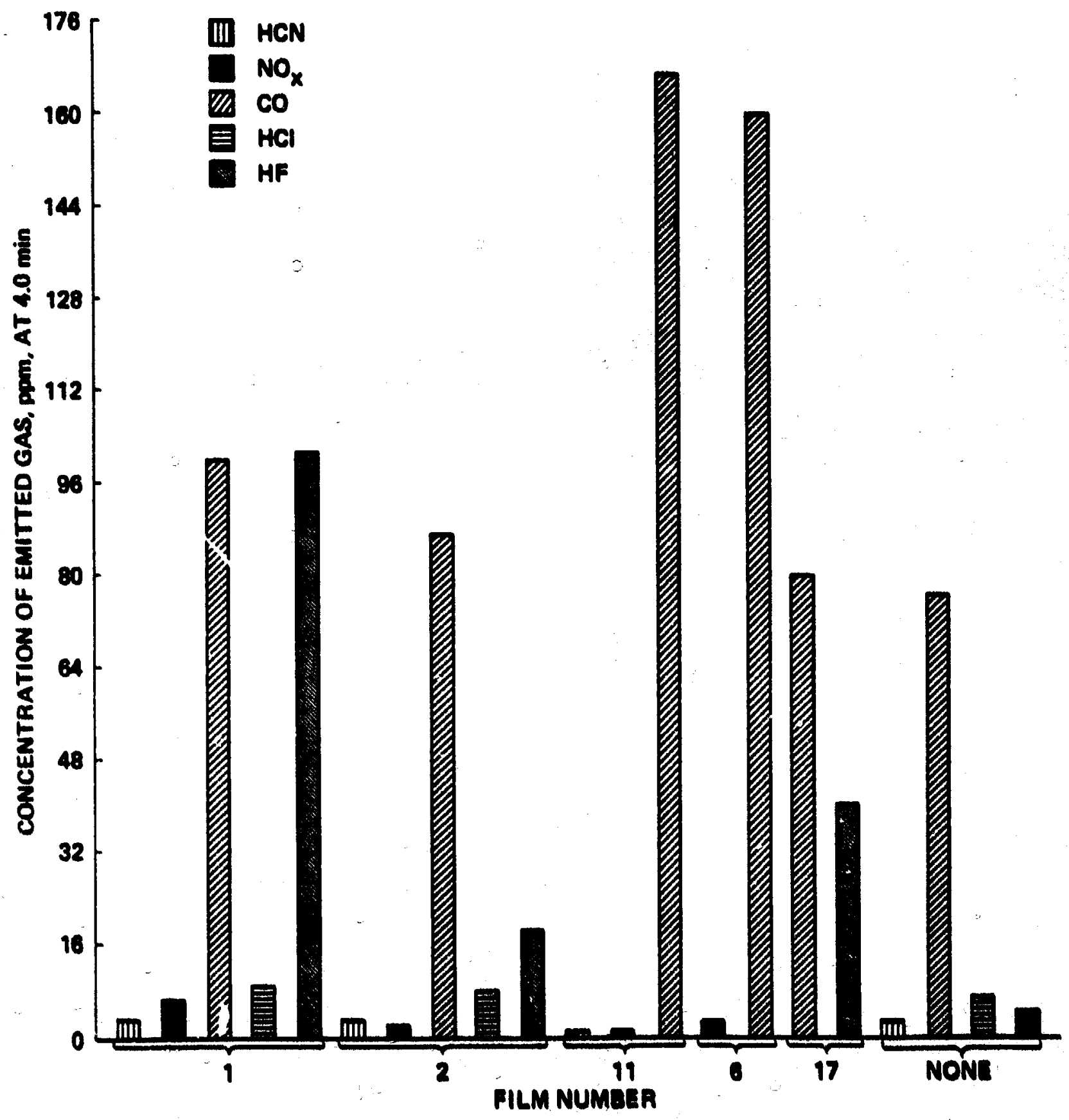

F18. 12 


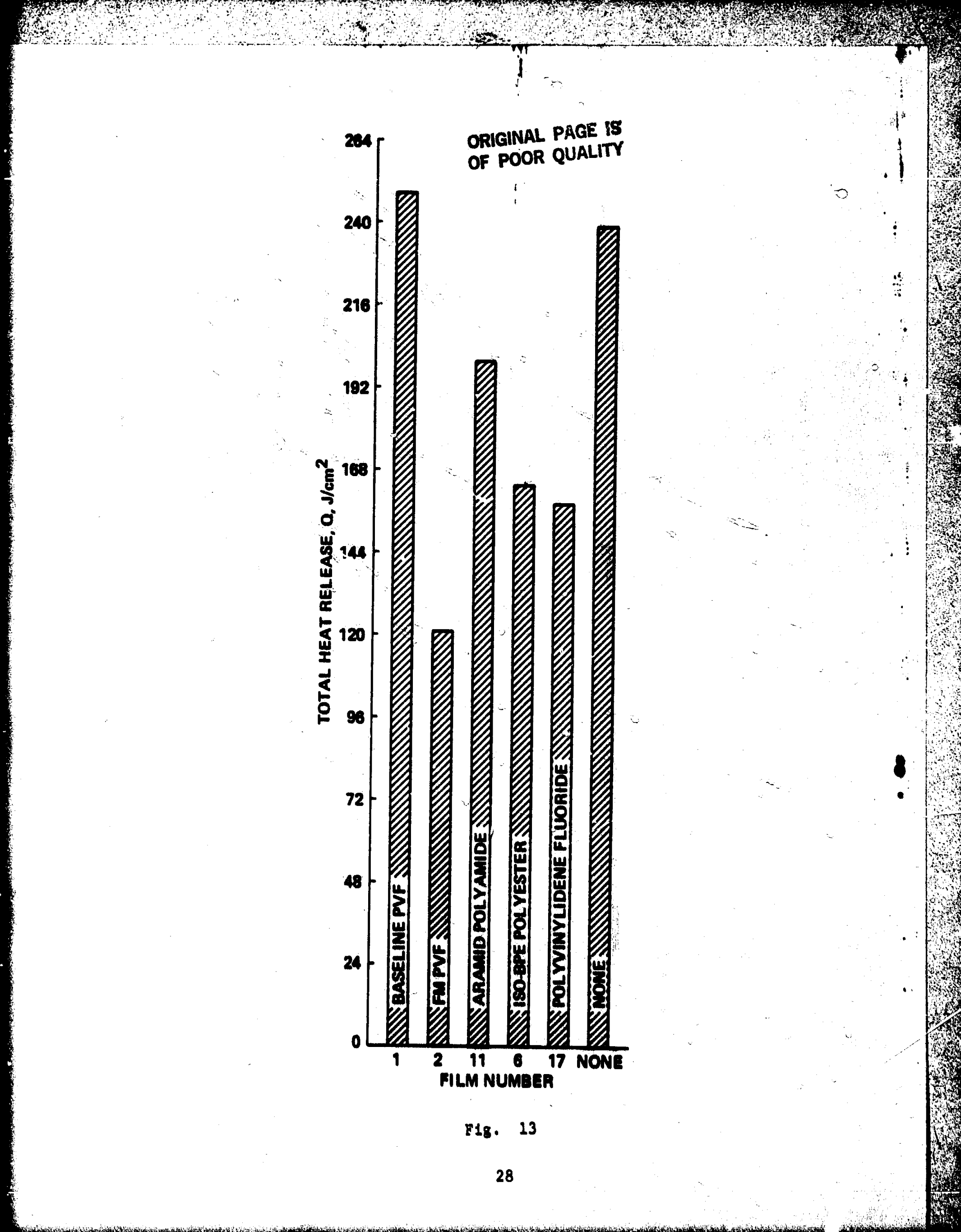


ORIGINAL PAGE IS
OF POOR QUALITY

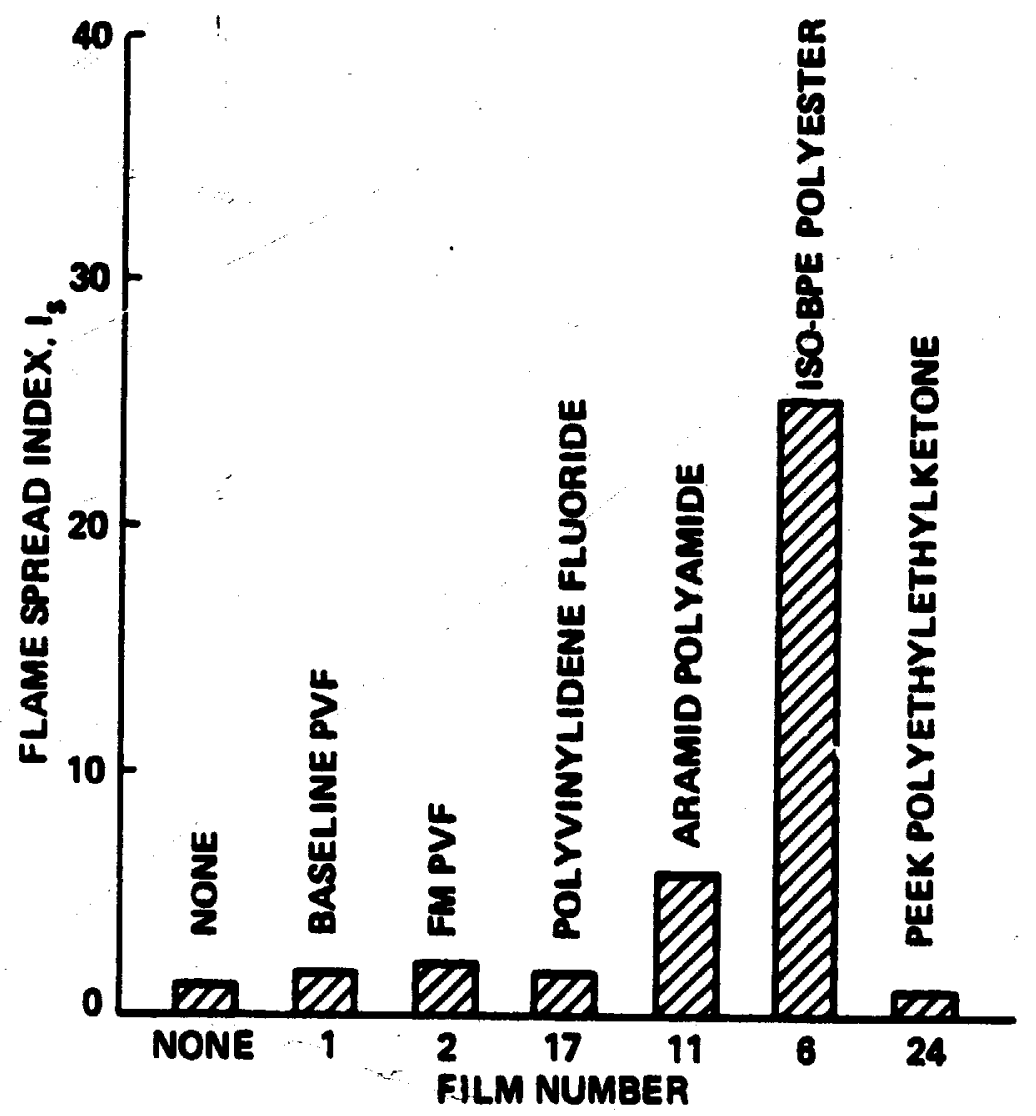

F18. $\quad 14$ 


\section{ORIGINAL PAGE IS OF POOR QUALTT}

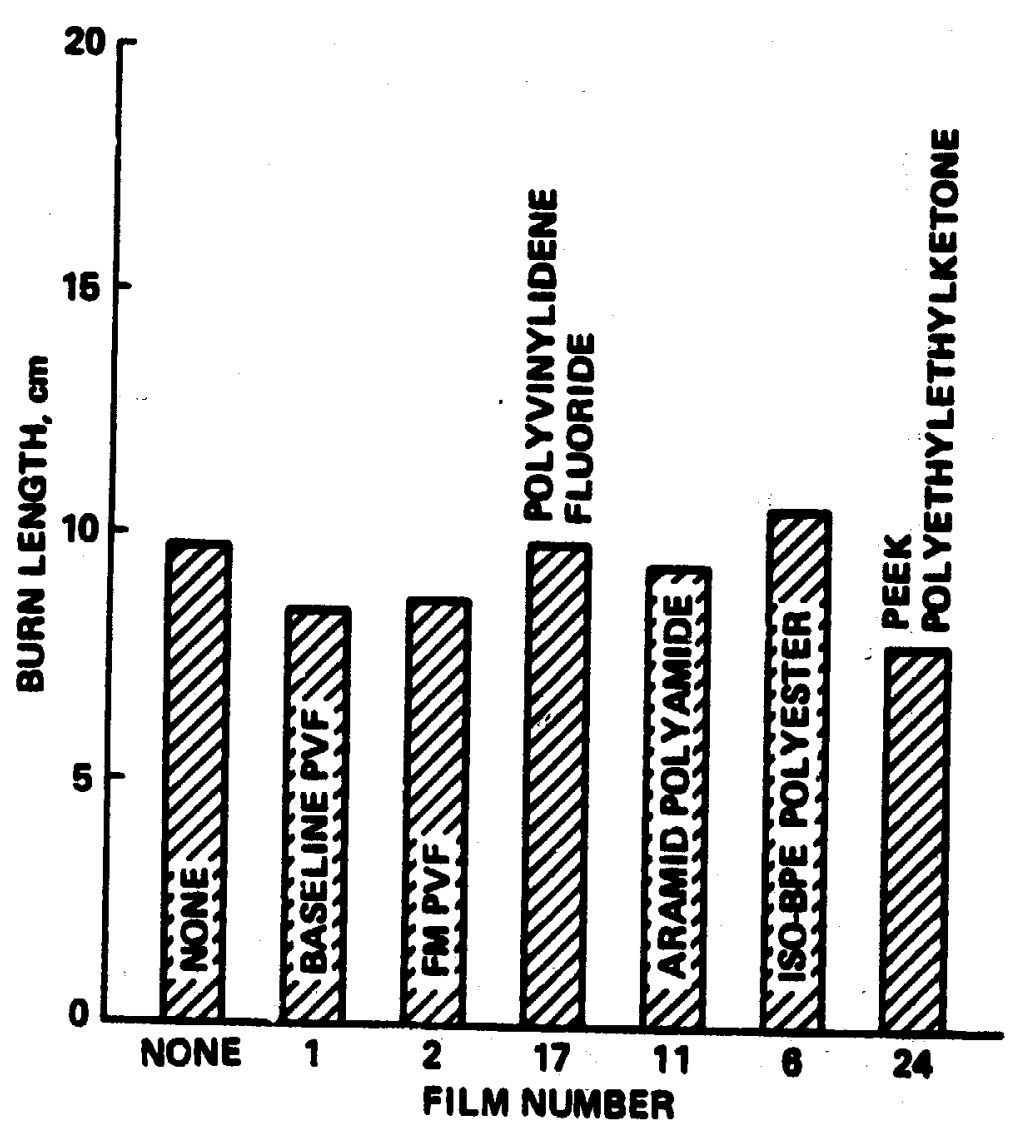

F18. $\quad 15$ 


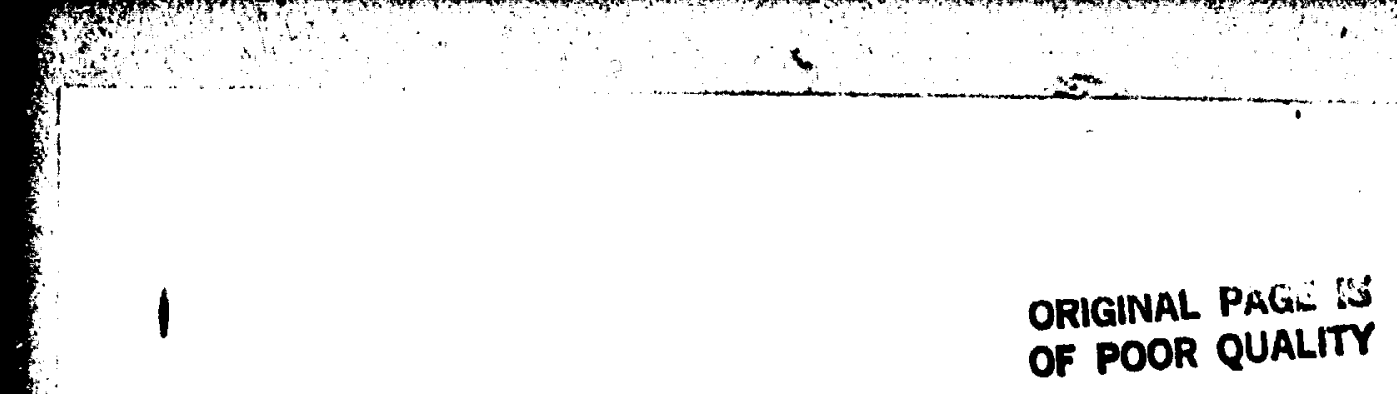

ORIGINAL PAGII IS
OF POOR QUALITY

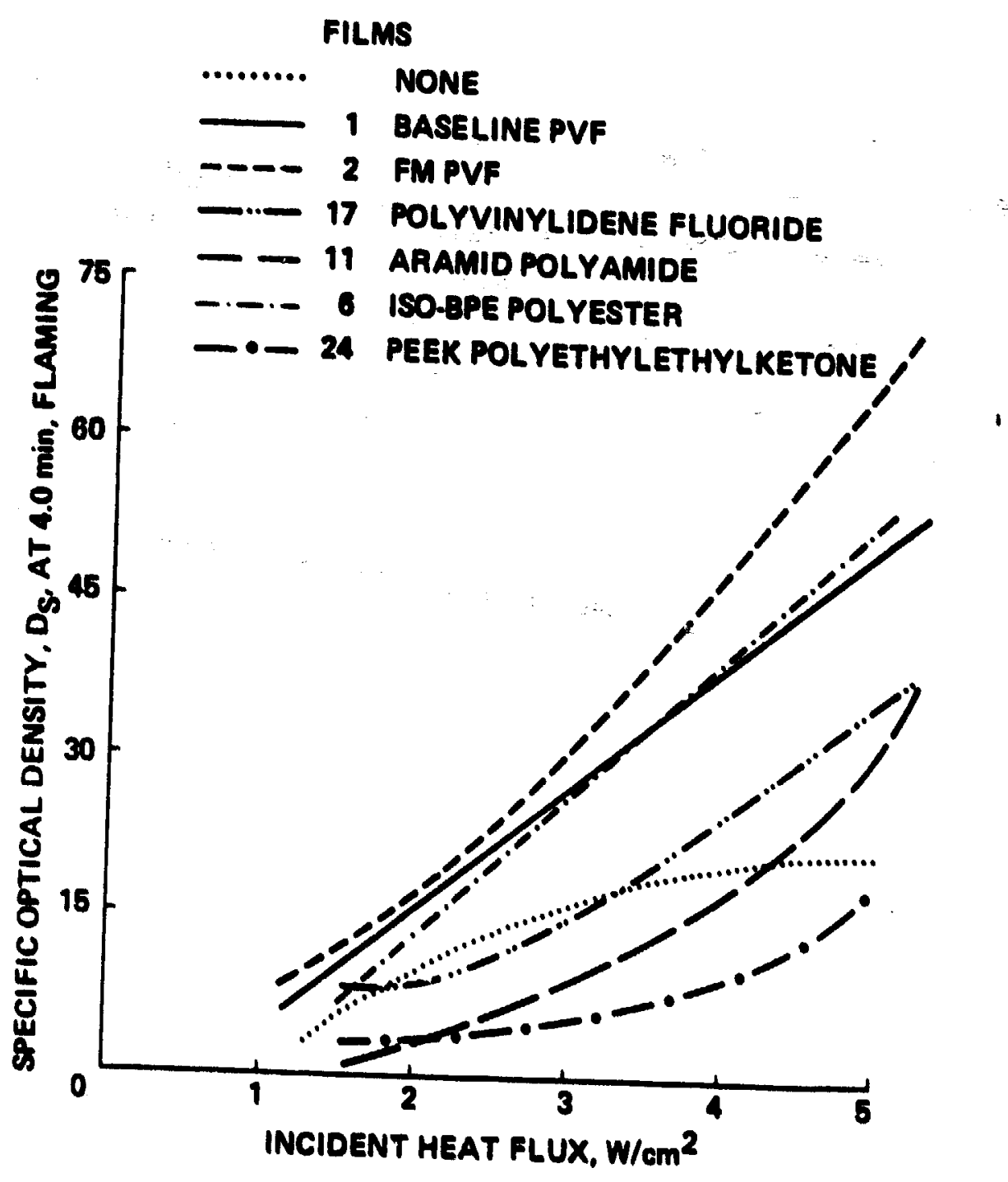

F18. 16 
ORIGINAL PAGE IS

OF POOR QUALITY

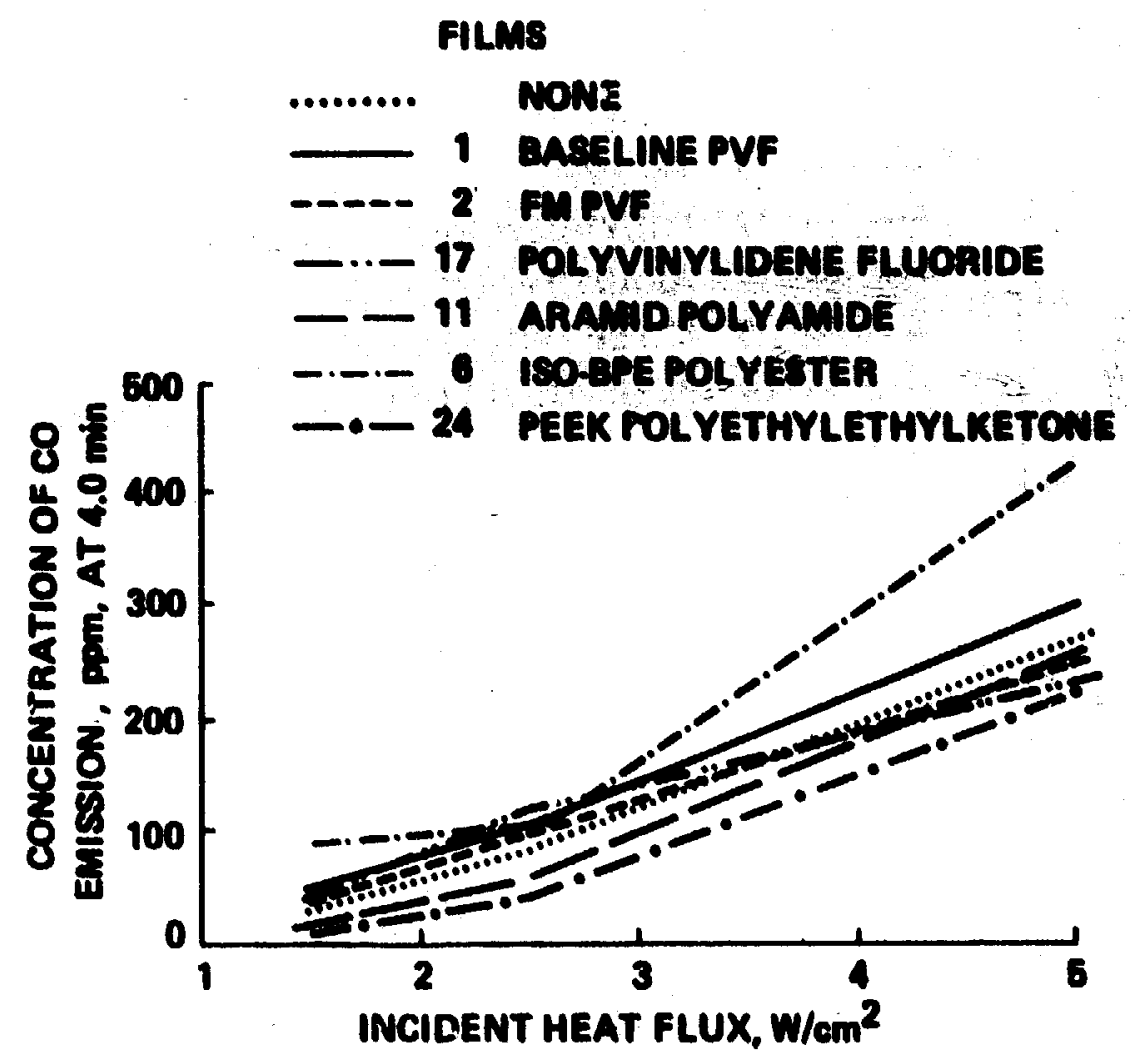

518. 17 
ORIGINAL PAGE IS

OF POOR QUALITY

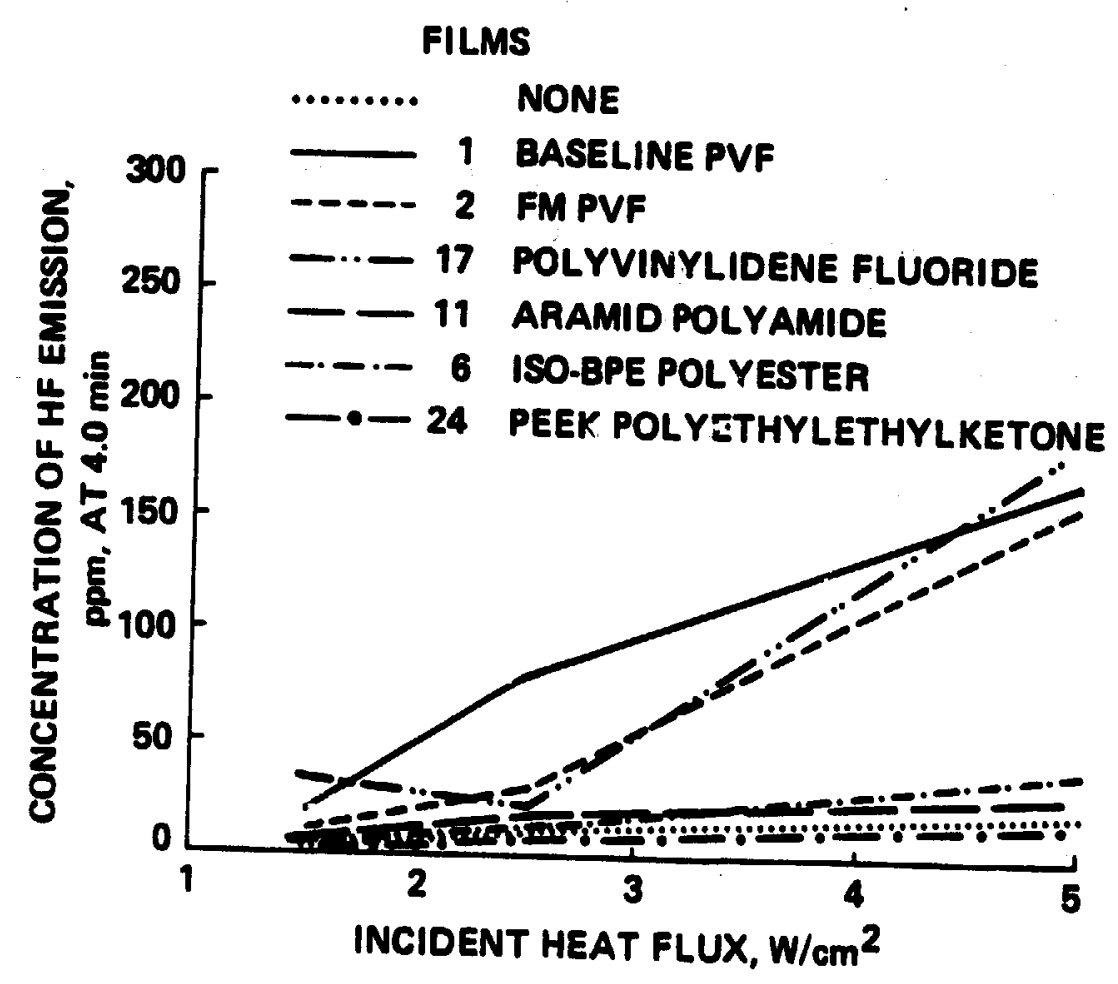

E18. $\quad 18$ 